\title{
Optimal Insulin Treatment in Syngeneic Islet Transplantation
}

\author{
Juan F. Merino, Victor Nacher, Mercè Raurell, Montserrat Biarnés, Joan Soler, and Eduard Montanya \\ Laboratory of Diabetes and Experimental Endocrinology, Endocrine Unit, CSUB-Hospital de Bellvitge, \\ University of Barcelona, Barcelona, Spain
}

\begin{abstract}
Insulin-induced normoglycemia has shown to have a beneficial effect on the outcome of pancreatic islets transplanted to diabetic recipients. The aim of the study was to identify the insulin treatment that can maximize its beneficial effect on islet transplants. Six groups of streptozotocin diabetic C57B1/6 mice were transplanted (Tx) with 100 syngeneic islets, an insufficient beta cell mass to restore normoglycemia, and were treated with insulin as follows: group $1(n=9)$ : from day 10 before Tx to day 14 after Tx; group $2(n$ = 11): from day 6 before Tx to Tx day; group $3(n=11)$ : from Tx day to day 6 after Tx; group $4(n=7)$ : from Tx day to day 14 after Tx; group $5(n=8)$ : from day 10 to day 24 after Tx; group $6(n=18)$ : Tx mice were not treated with insulin. Sixty days after Tx, normoglycemia was achieved in $100 \%$ of mice in groups 1,4 , and 5 , in $73 \%$ of mice in group 2 , and in only $45 \%$ and $33 \%$ of mice in groups 3 and 6 , respectively $(p<0.01)$. Intraperitoneal glucose tolerance, determined only in normoglycemic mice, was similar in groups $1,2,4$, and normal controls. In contrast, normoglycemic mice from groups 3,5 , and 6 , exposed to more severe and prolonged hyperglycemia after $\mathrm{Tx}$, showed higher glucose values after glucose injection, suggesting that hyperglycemia had a long-lasting deleterious effect on transplanted beta cell function. The initially transplanted beta cell mass was maintained in the grafts of normoglycemic mice, but was severely reduced in hyperglycemic mice. Transplanted beta cell mass was similar in normoglycemic groups with normal or impaired glucose tolerance, indicating that impaired glucose tolerance was not due to reduced beta cell mass. In summary, the beneficial effect of insulin-induced normoglycemia on transplanted islets was maximal when insulin treatment was maintained the initial 14 days after transplantation. Exposure to sustained hyperglycemia initially after transplantation had a long-lasting deleterious effect on transplanted islets.
\end{abstract}

Key words: Islet transplantation; Insulin; Glucose toxicity; Beta cell mass

\section{INTRODUCTION}

Chronically elevated glucose levels can cause beta cell dysfunction $(18,30,36)$, and transplanted islets exposed to sustained hyperglycemia have shown impaired beta cell function $(8,10,15,35)$, limited replicative capacity, and reduced beta cell mass $(23,24,26)$. In addition, hyperglycemia reduced blood perfusion and delayed revascularization of the graft in several, but not all, studies $(11,21,33)$.

In the initial days after transplantation hyperglycemia has been related to increased beta cell death (4) and reduced beta cell mass $(4,24)$. However, islets exposed to mild hyperglycemia several weeks after transplantation showed increased beta cell replication and mass $(12,25,27)$, suggesting that transitory hyperglycemia could have a positive effect on transplanted islets. Thus, the effects of hyperglycemia on transplanted islets could depend on the severity, duration, and timing of exposure to hyperglycemia.
Insulin treatment has shown a beneficial effect on transplanted islets $(14,23,28)$. We recently reported that normoglycemic, insulin-treated diabetic mice achieved permanent normoglycemia with the transplantation of an otherwise insufficient beta cell mass (23); in contrast, non-insulin-treated mice remained hyperglycemic. However, a few hyperglycemic, non-insulin-treated mice eventually achieved normoglycemia after transplantation. Interestingly, these animals showed an abnormal glucose tolerance compared to mice that were normoglycemic when transplanted, suggesting that beta cell function was impaired by the previous exposure to hyperglycemia. Therefore, the aim of this study was to identify the insulin administration regime that could maximize the beneficial effect of insulin on transplanted islets. In addition, we sought to determine whether transitory exposure of transplanted islets to hyperglycemia immediately after transplantation could have a long-lasting deleterious effect on transplanted beta cells. 


\section{MATERIALS AND METHODS}

Male inbred $\mathrm{C} 57 \mathrm{Bl} / 6$ mice (B\&K Universal, Humberside, UK) aged 7-10 weeks, were used as donors and recipients of transplantation. The recipients were made diabetic by a single IP injection of streptozotocin (Sigma Immunochemicals, St. Louis, MO) $180 \mathrm{mg} / \mathrm{kg}$ b.wt., freshly dissolved in citrate buffer ( $\mathrm{pH} 4.5)$. Before transplantation, diabetes was confirmed by the presence of hyperglycemia, weight loss, and polyuria. Only those mice with a blood glucose higher that $20 \mathrm{mmol} / \mathrm{l}$ were transplanted. Blood glucose was determined between 0900 and $1100 \mathrm{~h}$ in nonfasting conditions. Blood was obtained from the snipped tail with a heparinized microcapillary tube and glucose was measured with a portable glucose meter (Reflolux II, Boehringer Mannheim Biochemicals, Mannheim, Germany). Animals were kept under conventional conditions in climatized rooms with free access to tap water and standard pelleted food.

\section{Experimental Groups and Insulin Treatment}

Six groups of STZ-diabetic mice were studied. Five to 14 days after STZ injection, diabetic mice were randomly distributed among groups and treated as summarized in Figure 1. All six groups received a 100 syngeneic islet transplantation under the left kidney capsule on day 0 . This is an insufficient beta cell mass to consis- tently restore normoglycemia and most mice were expected to remain hyperglycemic after transplantation. In addition, groups 1 to 5 were treated with sustained release insulin implants (LinBits, Linshin Canada, Inc., Scarborough, Canada) as previously described (23). Groups were treated as follows: group $1(n=9)$ : from day 10 before transplantation to day 14 after transplantation; group $2(n=11)$ : from day 6 before transplantation to transplantation day; group $3(n=11)$ : from transplantation day to day 6 after transplantation; group $4(n=7)$ : from transplantation day to day 14 after transplantation; group $5(n=8)$ : from day 10 to day 24 after transplantation. Group $6(n=18)$ was not treated with insulin. All grafts were harvested 60 days after transplantation. A control group $(n=6)$ of normal nontransplanted mice had their blood glucose and body weight determined weekly.

The rational for insulin treatment in group 1 was to maintain normoglycemia (blood glucose $<9.0 \mathrm{mmol} / \mathrm{l}$; mean \pm 2 SD of blood glucose in control group) from at least day 6 before transplantation to the completion of vascularization on day 14 after transplantation. In groups 2 and 3, insulin treatment was given to assess the effects of short-term normoglycemia immediately before (group 2) or after (group 3) transplantation. In group 4 treatment was to maintain normoglycemia throughout

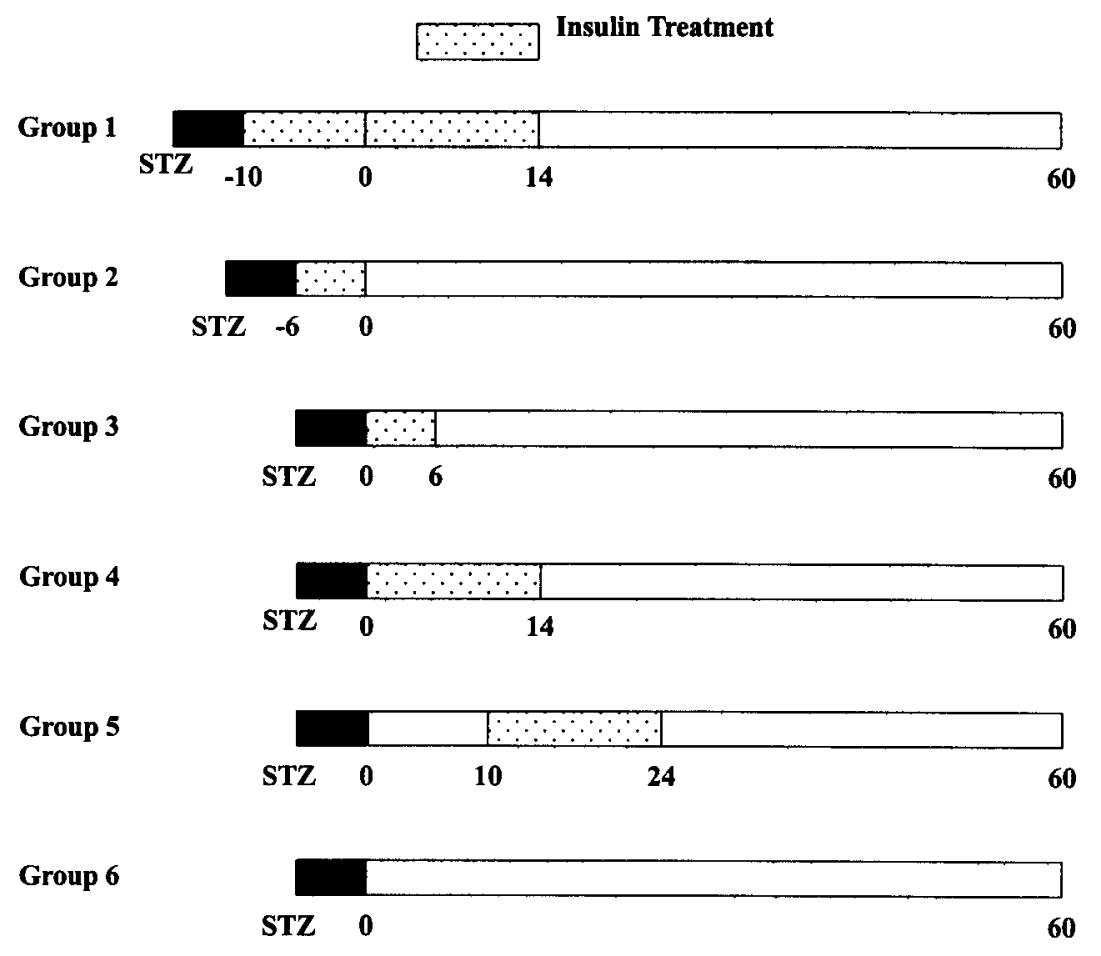

Figure 1. Experimental protocol. STZ, streptozocin injection. Numbers indicate days before or after transplantation. In all groups, mice were transplanted on day 0 and grafts were harvested on day 60. 
the revascularization period, and in group 5 to determine the effects of delayed normoglycemia after an initial exposure to severe hyperglycemia. As intended, groups 1 and 2 were normoglycemic on transplantation day, and mice were transplanted after $7.3 \pm 0.6$ and $2.4 \pm 0.3$ days of normoglycemia; in group 1 insulin treatment maintained normoglycemia 14 additional days after transplantation. In contrast, groups 3 to 5 were severely hyperglycemic when transplanted. In groups 3 and 4 , insulin treatment restored normoglycemia in the immediate posttransplantation period for $2.2 \pm 0.3$ and $10.3 \pm$ 0.8 days, respectively. In group 5 , insulin treatment on days 10 to 24 after transplantation maintained normoglycemia $10.5 \pm 0.5$ days.

\section{Islet Isolation, Transplantation, and Graft Harvesting}

Islets were isolated by collagenase (collagenase $\mathrm{P}$, Boehringer Mannheim Biochemicals) digestion of the pancreas as previously described (23). Isolated islets were handpicked under a stereomicroscope two or three times until a population of pure islets was obtained. Only those islets $>75$ and $<250 \mu \mathrm{m}$ in diameter were collected and counted into groups of 100 islets, which were transplanted under the left kidney capsule of the recipient on the day of the isolation. After transplantation, the capsulotomy was cauterized with a disposable low-temperature cautery pen (F.L. Fischer Bipolator, Berlin, Germany) and the lumbar incision was sutured. To harvest the graft, the kidney was exposed with the mouse under light ether anesthesia. The graft was identified as a white patch in normoglycemic mice, and a more translucent graft was found in hyperglycemic mice. The kidney capsule surrounding the graft was incised and removed with the graft.

\section{Intraperitoneal Glucose Tolerance Test (IPGTT)}

IPGTT was performed on days 54-58 after transplantation in all normoglycemic animals and in control mice of similar age. Between 1100 and $1200 \mathrm{~h}$, after a $2-\mathrm{h}$ fasting, nonanesthetized mice were injected with a $10 \%$ glucose solution (ERN Laboratory, Barcelona, Spain) $1.5 \mathrm{~g} / \mathrm{kg} / \mathrm{b}$.wt. IP. Blood glucose was determined at the time of injection and 30,60, 90, 120, and $180 \mathrm{~min}$ later. Total area under the curve (AUC) was calculated with the trapezoidal rule method.

\section{Immunocytochemistry}

After removal, the graft was immediately immersed in Bouin's fixative. Then any excess of Bouin's was carefully removed by capillary action and the weight of the graft was determined on a Mettler balance type A240 reading to $0.01 \mathrm{mg}$ (Mettler Instruments Corporation. Highstown, NJ) and processed for paraffin embedding. Sections $(2 \mu \mathrm{m})$ were stained with inmunoperoxidase for the endocrine non-beta cells of the graft with a cocktail of antibodies antiglucagon, antisomatostatin, and antipancreatic polypeptide (Dako Corporation, Carpinteria, CA) (27). The sections were stained with 3,3'-diaminobenzimide tetrahydrochloride (Sigma Immunochemical) and hydrogen peroxide (Merck, Darmstadt, Germany). We stained the endocrine non-beta cells instead of the beta cells because chronic severe hyperglycemia, expected in some groups, is associated with beta cell degranulation, resulting in weak or negative staining of beta cells. To validate the method, graft sections from normoglycemic mice were stained for beta cells with a guinea pig anti-swine insulin antibody (Dako Corporation) and the results compared to those obtained with the staining of endocrine non-beta cells.

\section{Beta Cell Mass}

Methods used for measurement of beta cell mass have been described in detail (24). Beta cell mass was measured by point counting morphometry on immunoperoxidase-stained sections of grafts with an Olympus BH2 microscope connected to a video camera with a color monitor. A 48-point grid was used to obtain the number of intercepts over beta cells, over endocrine non-beta cells, and over other tissue. The beta cell mass of islets at the time of transplantation was determined in eight groups of 100 islets isolated on different days.

\section{Statistical Analysis}

Results were expressed as mean \pm SEM. The significance of the difference in categorical variables was tested with the chi-square test. The significance of the difference in continuous variables was tested using the unpaired Student's $t$-test, two-tailed, and for multiple comparisons between groups the one-way analysis of variance (ANOVA). The Bonferroni correction was used to determine specific differences between means when determined as significant by ANOVA. When results did not show a normal distribution the Kruskal-Wallis test was used. A value of $p<0.05$ was considered significant.

\section{RESULTS}

\section{Metabolic Evolution}

The characteristics of experimental groups are summarized in Table 1. All groups were comparable in blood glucose and body weight when injected with streptozotoocin, as well as when insulin treatment was started. When insulin treatment was discontinued, all mice in group 1 remained normoglycemic until the end of the study; in contrast, hyperglycemia recurred in groups 2 to 5 . After transitory hyperglycemia, definitive normoglycemia was achieved in eight $(73 \%)$ mice of group 2, five (45\%) mice of group 3, all mice of groups 
Table 1. Characteristics of Experimental Groups

\begin{tabular}{lcccccc}
\hline & & \multicolumn{3}{c}{ Blood Glucose (mmol/1) } \\
\cline { 3 - 7 } Group & $\begin{array}{c}\text { Days of Insulin } \\
\text { Treatment* }\end{array}$ & Day STZ & $\begin{array}{c}\text { First Day } \\
\text { Insulin }\end{array}$ & Day Tx & $\begin{array}{c}\text { Day Graft } \\
\text { Removal }\end{array}$ & $\begin{array}{c}\text { Day 7 After } \\
\text { Graft Removal }\end{array}$ \\
\hline $1(n=9)$ & -10 to 14 & $7.8 \pm 0.4$ & $26.9 \pm 0.7$ & $6.3 \pm 0.9$ & $7.9 \pm 0.5$ & $26.5 \pm 0.8$ \\
$2(n=11)$ & -6 to 0 & $7.6 \pm 0.3$ & $27.0 \pm 0.6$ & $5.6 \pm 1.1$ & $13.4 \pm 2.7 \dagger$ & $26.0 \pm 0.5$ \\
$3(n=11)$ & 0 to 6 & $7.7 \pm 0.3$ & $26.7 \pm 0.6$ & $26.7 \pm 0.6$ & $17.8 \pm 3.1 \ddagger$ & $27.2 \pm 0.4$ \\
$4(n=7)$ & 0 to 14 & $7.4 \pm 0.3$ & $26.3 \pm 0.9$ & $26.3 \pm 0.9$ & $8.2 \pm 0.6$ & $27.2 \pm 0.5$ \\
$5(n=8)$ & 10 to 24 & $6.9 \pm 0.5$ & $25.7 \pm 1.6$ & $24.3 \pm 1.0$ & $7.7 \pm 0.9$ & $>27.8$ \\
$6(n=18)$ & - & $7.3 \pm 0.3$ & - & $27.3 \pm 0.4$ & $15.6 \pm 2.3 \ddagger$ & $>27.8$ \\
Control $(n=6)$ & - & $8.1 \pm 0.5$ & $7.5 \pm 0.2$ & $7.5 \pm 0.3$ & $7.1 \pm 0.2$ & \\
\hline
\end{tabular}

Values are mean \pm SEM. In the control group, data show blood glucose values determined in normal non-STZ-injected and non-insulin-treated mice of similar age as STZ-injected and transplanted groups.

*Day 0 corresponds to transplantation day.

$\dagger p<0.01$ vs. control group.

$\ddagger p<0.01$ vs all other normoglycemic groups.

4 and 5, and in six (33\%) mice of group $6(p<0.01$ between groups 3 and 6 and all other groups) (Fig. 2). In groups 2 and 4, transitory hyperglycemia after transplantation was mild $(<14 \mathrm{mmol} / \mathrm{l})$, and definitive normoglycemia was achieved $12.6 \pm 2.9$ and $22.6 \pm 3.7$ days, respectively, after transplantation. In contrast, groups 3,5, and 6 experienced severe hyperglycemia ( $>20 \mathrm{mmol} / \mathrm{l}$ ) 10 or more days after transplantation, and definitive normoglycemia was not achieved until day $33.4 \pm 5.3$ in group 3, day $30.6 \pm 2.4$ in group 5, and day $35.1 \pm 4.0$ in group 6 . Mice that eventually achieved normoglycemia and those that remained hyperglycemic showed similar characteristics when they were injected with streptozotocin, started on insulin, or transplanted.

In all normoglycemic mice recurrence of hyperglycemia was confirmed on days 2 and 7 after graft harvest-

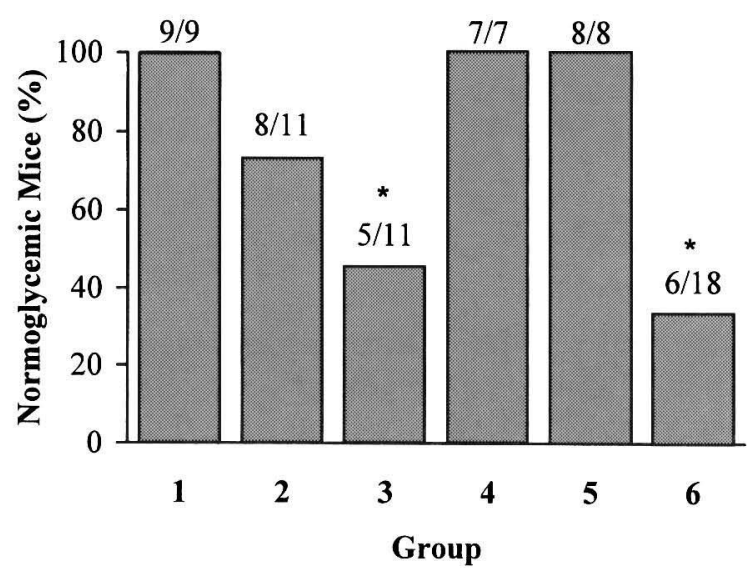

Figure 2. Mice normoglycemic at the end of study. Numbers on the $x$-axis correspond to transplanted groups shown in Figure 1 . Numbers on top of the columns show mice that maintained normoglycemia at the end of follow-up. ${ }^{*} p<0.01$ between groups 3 and 6 , and all other groups. ing. In two mice blood glucose did not achieve 20 $\mathrm{mmol} / \mathrm{l}$, and they were excluded from the study. Severe hyperglycemia $(>20 \mathrm{mmol} / \mathrm{l})$ and weight loss persisted in all mice on day 7 after graft harvesting, and were similar in all groups (Table 1).

Six hyperglycemic mice (one in group 2 , two in group 3, and three in group 6) were severely ill after the withdrawal of insulin treatment and required additional transitory (less that 7 days) insulin administration; all these mice were hyperglycemic at the end of the study.

\section{IPGTT}

IPGTT test was performed only in normoglycemic mice. After IP glucose injection, glucose levels at specific time points and glucose AUC were similar in control group and normoglycemic mice of groups 1,2, and 4 (Fig. 3). Group 5 had higher glucose values after 120 min (group 5: $13.7 \pm 1.0 \mathrm{mmol} / /$; control group: $9.3 \pm$ $0.5 \mathrm{mmol} / 1 ; p=0.002$ ) and group 6 showed a higher glucose peak (group 6: $22.4 \pm 1.8 \mathrm{mmol} / \mathrm{l}$; control group: $16.0 \pm 0.6 \mathrm{mmol} / \mathrm{l} ; p=0.006)$. The AUC was higher in groups $3(3584 \pm 179 \mathrm{mM} / \mathrm{min}), 5(3629 \pm 177 \mathrm{mM} /$ $\mathrm{min})$, and $6(3916 \pm 324 \mathrm{mM} / \mathrm{min})$ compared to the control group ( $2890 \pm 125 \mathrm{mM} / \mathrm{min}, p<0.008)$ (Fig. 3).

\section{Beta Cell Mass}

When graft sections from six normoglycemic mice were stained for the endocrine non-beta cells or for the beta cells, beta cell mass was $0.20 \pm 0.03$ and $0.18 \pm$ $0.04 \mathrm{mg}(r=0.99)$, respectively, confirming the validity of staining the endocrine non-beta cells to determine beta cell mass. The initially transplanted beta cell mass was maintained in all normoglycemic grafts at the end of follow-up, with no significant differences among groups. In contrast, beta cell mass was severely reduced in hyperglycemic mice (Table 2). There was no correlation between the individual beta cell mass values in 

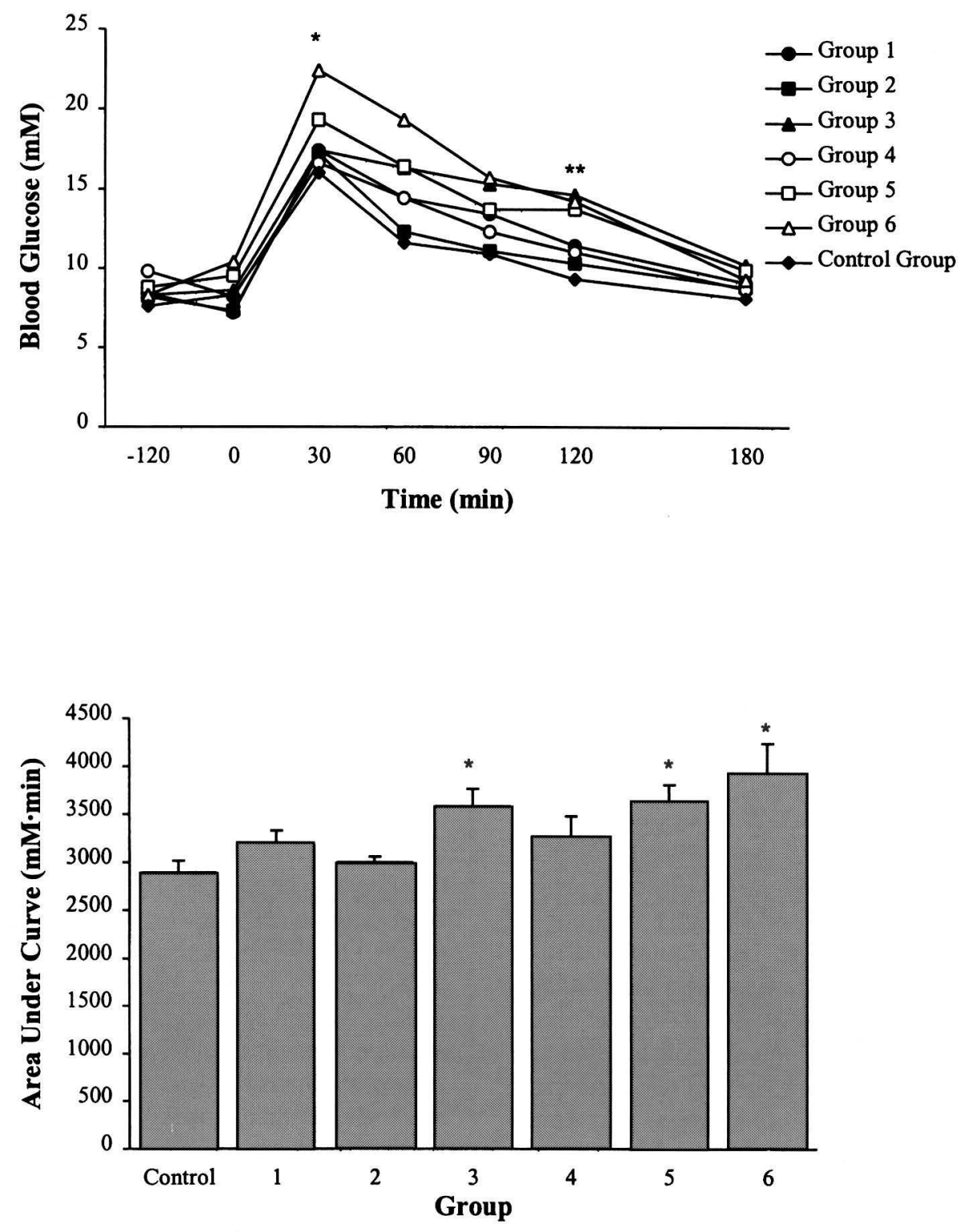

Figure 3. Intraperitoneal glucose tolerance test in mice that achieved normoglycemia after transplantation. Groups 1 to 6 correspond to transplanted groups shown in Figure 1. Upper panel: ${ }^{*} p<$ 0.05 between group 6 and control, ${ }^{*} p<0.05$ between group 5 and control. Lower panel: $* p<$ 0.008 between control group and groups 3,5 , and 6 . Values are mean $\pm \mathrm{SE}$.

the grafts and the glucose levels after IP glucose challenge.

\section{DISCUSSION}

In this study, we have shown that the beneficial effect of insulin treatment on the outcome of syngeneically transplanted islets was determined by the timing and duration of insulin-induced normoglycemia in the diabetic recipients of the transplants. The beneficial effect of insulin was maximal in groups 1 and 4 , which maintained normoglycemia throughout the initial 14 days after transplantation; all mice achieved definitive normogly- cemia and glucose tolerance was normal despite the transplantation of an otherwise insufficient beta cell mass. In contrast, the shorter 6-day posttransplantation treatment in group 3 did not improve the metabolic evolution compared to non-insulin-treated mice. A similar 6-day insulin treatment given exclusively before transplantation afforded some protection, and most mice achieved definitive normoglycemia, indicating that maintaining normoglycemia on transplantation day is beneficial. When insulin treatment was postponed and transplanted islets were initially exposed to hyperglycemia, the beneficial effect of insulin was reduced and, 
Table 2. Beta Cell Mass in Grafts

\begin{tabular}{lcc}
\hline Group & $\begin{array}{c}\text { Normoglycemic } \\
\text { Mice }(\mathrm{mg})\end{array}$ & $\begin{array}{c}\text { Hyperglycemic } \\
\text { Mice }(\mathrm{mg})\end{array}$ \\
\hline 1 & $0.21 \pm 0.03$ & - \\
2 & $0.18 \pm 0.02$ & $0.035 \pm 0.012^{*}$ \\
3 & $0.18 \pm 0.03$ & $0.084 \pm 0.022^{*}$ \\
4 & $0.19 \pm 0.02$ & - \\
5 & $0.27 \pm 0.03$ & - \\
6 & $0.21 \pm 0.03$ & $0.080 \pm 0.019^{*}$ \\
100 isolated islets & $0.21 \pm 0.01$ & - \\
\hline
\end{tabular}

Values are mean \pm SEM.

$*_{p}<0.05$ between hyperglycemic and normoglycemic mice.

even if normoglycemia was finally achieved, mice showed impaired glucose tolerance. Beta cell mass was similar in normoglycemic groups with normal and impaired glucose tolerance, indicating that impaired glucose tolerance was not due to reduced beta cell mass and suggesting that hyperglycemia had a long-lasting detrimental effect on transplanted beta cell function.

After transplantation, a minimum duration of insulininduced normoglycemia was required to improve the outcome of the graft. In group 3, 6 days of insulin after transplantation did not increase the percentage of mice that achieved definitive normoglycemia. In contrast, all mice in groups 1 and 4 achieved definitive normoglycemia after 14 days of insulin. The requirement of a minimum normoglycemic period after transplantation may be related to the effects of hyperglycemia on revascularization and oxygen requirement of transplanted beta cells. Transplanted islets are devoid of vascularization in the first days after transplantation, they begin to revascularize around day 4 after transplantation, and vascularization is completed after 10-14 days $(2,22)$. Although the effects of hyperglycemia on angiogenesis of transplanted islets have been controversial, it has been reported that revascularization of the graft can be delayed by hyperglycemia $(11,33)$. In addition, hyperglycemia could increase the hypoxia of transplanted islets because islets exposed to hyperglycemia have a higher oxygen requirement that cannot be met by diffusion in nonvascularized islets (6), resulting in beta cell death and compromised insulin secretion (7) of surviving islets. Our data give experimental support to the recent suggestion that prolongation of insulin treatment after transplantation may reduce the presence of early graft failure and extend the survival of the graft in type I diabetic patients (1).

The beneficial effects of maintaining normoglycemia on transplantation day were apparent in group 2, which was treated with insulin exclusively before transplantation. Only $27 \%$ of mice in this group did not achieve normoglycemia after transplantation. Short-term hyperglycemia has been shown to induce insulin resistance in diabetic animal models (31) and type I diabetic patients $(34,37)$, and correction of hyperglycemia improved insulin sensitivity $(17,32)$. Thus, normoglycemic, insulintreated recipients of islet grafts were probably more insulin sensitive than hyperglycemic mice. In a different model using $95 \%$ pancreatectomized rats, we reported that restoring normoglycemia required a higher beta cell mass than maintaining normoglycemia, and suggested that the different insulin sensitivity of normoglycemic and hyperglycemic recipients had played a role in the different beta cell mass requirement (25). The reduced insulin resistance of normoglycemic group 2 mice on transplantation day may have facilitated the achievement of definitive normoglycemia with the transplantation of a low beta cell mass.

Hyperglycemia had a long-lasting deleterious effect on transplanted beta cell function, even when normoglycemia was eventually achieved. Mice exposed to sustained and severe hyperglycemia after transplantation showed an abnormal tolerance more than 3 weeks after the restoration of normoglycemia. In contrast, mice persistently normoglycemic after transplantation or exposed to short-term moderate hyperglycemia showed normal glucose tolerance at the end of follow-up. The detrimental effect of chronic exposure to high glucose concentrations on beta cell function has been shown in cultured rodent $(13,29)$ and human $(5,9)$ islets, and in animal models $(3,19)$. In transplanted islets, the deleterious effect of hyperglycemia on beta cell function and the beneficial effects of normoglycemia have been described in mouse and human islets $(8,10,15,35)$. Islets syngeneically transplanted to normoglycemic insulin-treated recipients showed preserved insulin content compared to islets exposed to hyperglycemia and were able to increase their beta cell mass to meet an increased metabolic demand (23). Human islets transplanted to diabetic nude mice showed the recovery of normal insulin content, insulin biosynthesis, glucose oxidation, and expression of insulin mRNA when normoglycemia was restored after sustained hyperglycemia (8). However, defective glucose-induced insulin release was still found after 2 weeks of normoglycemia, suggesting that the insulin secretion defect induced by hyperglycemia could be of long duration or even permanent (10). The similar beta cell mass that we found in grafts of mice with impaired glucose tolerance, and previously exposed to sustained and severe hyperglycemia, and mice with normal glucose tolerance further supports the concept that hyperglycemia may have long-term deleterious effects on beta cell function. In this study, we used a mouse strain that has shown resistance to glucose-induced beta cell dysfunction $(16,20)$. Thus, it is possible that the beneficial 
effect of insulin-induced normoglycemia could be even higher in human transplanted islets, which have shown a high sensitivity to the deleterious effects of high glucose concentrations (13).

In summary, both duration and timing of insulin-induced normoglycemia determined the beneficial effects on transplanted islets: when islets were transplanted to normoglycemic insulin-treated recipients the outcome of the transplants was partially improved, but the beneficial effect of normoglycemia was maximal when insulin treatment was maintained throughout the revascularization period. Exposure to sustained hyperglycemia initially after transplantation had a long-term deleterious effect on transplanted beta cells.

ACKNOWLEDGMENTS: This work was supported by grants FIS-95/1108 and SAF-97/0118 from the Ministry of Health of Spain, and the 1996 Research Grant of the Catalan Diabetes Association. J. F. Merino, V. Nacher, and M. Raurell were the recipients of fellowships from the Commision for Research and Technology of the Government of Catalonia, FIS-95/I108, and Fundació August Pi i Sunyer, respectively.

\section{REFERENCES}

1. Alejandro, R.; Lehmann, R.; Ricordi, C.; Kenyon, N. S.; Angelico, M. C.; Burke, G.; Esquenazi, V.; Nery, J.; Betancourt, A. E.; Kong, S. S.; Miller, J.; Mintz, D. H. Long term function (6 years) of islet allografts in type 1 diabetes. Diabetes 46:1983-1989; 1997.

2. Andersson, A.; Korsgren, O.; Jansson, L. Intraportally transplanted pancreatic islets revascularized from hepatic arterial system. Diabetes 38(Suppl. 1):192-195; 1989.

3. Bonner-Weir, S.; Trent, D. F.; Weir, G. C. Partial pancreatectomy in the rat and subsequent defect in glucoseinduced insulin release. J. Clin. Invest. 71:1544-1554; 1983.

4. Davalli, A. M.; Scaglia, L.; Zangen, D. H.; Hollister, J.; Bonner-Weir, S.; Weir, G. C. Vulnerability of islets in the immediate posttransplantation period. Dynamic changes in structure and funtetion. Diabetes 45:1161-1167; 1996.

5. Davalli, A. M.; Ricordi, C.; Socci, C.; Braghi, S.; Bertuzzi, F.; Fattor, B.; Di Carlo, V.; Pontiroli, A. E.; Pozza, G. Abnormal sensitivity to glucose of human islets cultured in a high glucose medium: Partial reversibility after an additional culture in a normal glucose medium. J. Clin. Endocrinol. Metab. 72:202-208; 1991.

6. Dionne, K. E.; Colton, C. K.; Yarmush, M. L. Effect of oxygen on isolated pancreatic tissue. Trans. Am. Soc. Artif. Intern. Org. XXXV:739-741; 1989.

7. Dionne, K. E.; Colton, C. K.; Yarmush, M. L. Effect of hypoxia on insulin secretion by isolated rat and canine islets of Langerhans. Diabetes 42:12-21; 1993.

8. Eizirik, D. L.; Jansson, L.; Flodstrom, M.; Hellerström, C.; Andersson, A. Mechanisms of defective glucose-induced insulin release in human pancreatic islets transplanted to diabetic nude mice. J. Clin. Endocrinol. Metab. 82:2660-2663; 1997.

9. Eizirik, D.; Korbutt, G. S.; Hellerström, C. Prolonged exposure of human pancreatic islets to high glucose concentrations in vitro impairs the beta cell function. J. Clin. Invest. 90:1263-1268; 1992.

10. Jansson, L.; Eizirik, D. L.; Pipeleers, D. G.; Borg, L. A.;
Hellerström, C.; Andersson, A. Impairment of glucose-induced insulin secretion in human pancreatic islets transplanted to diabetic nude mice. J. Clin. Invest. 96:721-726; 1995.

11. Jansson, S.; Sandler, S. Influence of hyperglycemia on blood perfusion of autotransplanted pancreatic islets in diabetic rats. Diabetes 38(Suppl. 1):196-198; 1989.

12. Juang, J. H.; Bonner-Weir, S.; Wu, Y. J.; Weir, G. C. Beneficial influence of glycemic control upon the growth and function of transplanted islets. Diabetes 43:1334$1339 ; 1994$.

13. Kaiser, N.; Corcos, A. P.; Sarel, I.; Cerasi, E. Monolayer culture of adult rat pancreatic islets on extracellular matrix: Modulation of B-cell function by chronic exposure to high glucose. Endocrinology 129:2067-2076; 1991.

14. Keymeulen, B.; Vetri, M.; Gorus, F.; Vanbrabandt, B.; Pipeleers, D. G. The effect of insulin treatment on function of intraportally grafted islets in streptozocin-diabetic rats. Transplantation 56:60-64; 1993.

15. Korsgren, O.; Jansson, L.; Andersson, A. Effects of hyperglycemia on function of isolated mouse pancreatic islets transplanted under kidney capsule. Diabetes 38:510-515; 1989.

16. Korsgren, O.; Janson, L.; Sandler, S.; Andersson, A. Hyperglycemia-induced $B$ cell toxicity. The fate of pancreatic islets transplanted into diabetic mice is dependent on their genetic background. J. Clin. Invest. 86:2161-2168; 1990.

17. Lager, I.; Lönnroth, P.; Von Schenck, H.; Smith, U. Reversal of insulin resistance in type 1 diabetes after treatment with continuous subcutaneous insulin infusion. Br. Med. J. 287:1001-1004; 1983.

18. Leahy, J. L.; Bonner-Weir, S.; Weir, G. C. $\beta$-cell dysfunction induced by chronic hyperglycemia. Diabetes Care 15: 442-455; 1992.

19. Leahy, J. L.; Weir, G. C. Evolution of abnormal insulin secretory responses during $48 \mathrm{~h}$. in vivo hyperglycemia. Diabetes 37:217-222; 1988 .

20. Leiter, E. H. Analysis of differential survival of syngeneic islets transplanted into hyperglycemic C57BL/6J versus C57BL/ksJ mice. Transplantation 44:401-406; 1987.

21. Menger, M. D.; Jaeger, S.; Walter, P.; Feifel, G.; Hammersen, F.; Messmer, K. Angiogenesis and hemodynamics of microvasculature of transplanted islets of Langerhans. Diabetes 38(Suppl. 1):199--201; 1989.

22. Menger, M. D.; Vajkoczy, P.; Leiderer, R.; Jager, S.; Messmer, $K$. Influence of experimental hyperglycemia on microvascular blood perfusion of pancreatic islets isografts. J. Clin. Invest. 90:1361-1369; 1992.

23. Merino, J. F.; Nacher, V.; Raurell, M.; Aranda, O.; Soler, J.; Montanya, E. Improved outcome of islet transplantation in insulin-treated diabetic mice: Effects on beta-cell mass and function. Diabetologia 40:1004-1010; 1997.

24. Montaña, E.; Bonner-Weir, S.; Weir, G. C. Beta cell mass and growth after syngeneic islet cell transplantation in normal and streptozocin diabetic C57BL/6 mice. J. Clin. Invest. 91:780-787; 1993.

25. Montaña, E.; Bonner-Weir, S.; Weir, G. C. Transplanted beta cell response to increased metabolic demand. Changes in beta cell replication and mass. J. Clin. Invest. 93:1577-1582; 1994.

26. Nacher, V.; Merino, J. F.; Raurell, M.; Soler, E.; Montanya, E. Normoglycemia restores $\beta$-cell replicative re- 
sponse to glucose in transplanted islets exposed to chronic hyperglycemia. Diabetes 47:192-196; 1998.

27. Nacher, V.; Raurell, M.; Merino, J. F.; Aranda, O.; Soler, J.; Montana, E. Beta cell growth and mass are preserved in long-term syngeneic islet transplantation in streptozocin-induced diabetic Lewis rats. Diabetes 45:1541$1546 ; 1996$.

28. Ozhato, H.; Porter, J.; Monaco, A.; Montana, E.; Maki, T. Minimun number of islets required to maintain euglycemia and their reduced immunogenicity after transplantation into diabetic mice. Transplantation 56:270-274; 1993.

29. Purrello, F.; Vetri, M.; Gatta, C.; Gullo, D.; Vigneri, R. Effects of high glucose on insulin secretion by isolated rat islets and purified beta cells and possible role of glycosylation. Diabetes 38:1417-1422; 1988.

30. Robertson, R. P.; Oson, L. K.; Zhang, H. J. Differentiating glucose toxicity from glucose desensitisation: A new message from the insulin gene. Diabetes 43:1085-1089; 1994.

31. Rossetti, L.; Shulman, G. I.; Zawalich, W.; DeFronzo, R. A. Effect of chronic hyperglycemia on in vivo insulin secretion in partially pancreatectomized rats. J. Clin. Invest. 80:1037-1044; 1987.
32. Rossetti, L.; Laughlin, M. R. Correction of chronic hyperglycemia with vanadate but not with phlorizin, normalizes in vivo glycogen repletion and in vitro glycogen synthase activity in diabetic skeletal muscle. J. Clin. Invest. 84; 892-899; 1989.

33. Sandler, S.; Jansson, L. Blood flow measurements in autotransplanted pancreatic islets on the rat. Impairment of the blood perfusion of the graft during hyperglycemia. J. Clin. Invest. 80:17-21; 1987.

34. Vuorinen-Markkola, H.; Koivisto, V. A.; Yki-Järvinen, H. Mechanisms of hyperglycemia-induced insulin resistance in whole body and skeletal muscle of type 1 diabetic patients. Diabetes 41:571-580; 1992.

35. Warnock, G. L.; Kneteman, N. M.; Rajotte, R. V. Effect of diabetes on the function of transplanted human islets of Langerhans. Transplant. Proc. 22:804-805; 1990.

36. Yki-Järvinen. Glucose toxicity. Endocr. Rev. 13:415-431; 1992.

37. Yki-Järvinen, H.; Helve, E.; Koivisto, V. A. Hyperglycemia decreases glucose uptake in type 1 diabetes. Diabetes $36: 892-896 ; 1987$. 